\title{
FORMULASI PEMBELAJARAN MATEMATIKA BAGI ANAK TUNAGRAHITA
}

\author{
Natasya D. P1, Erika², Marsi' ${ }^{3}$, Meidawati $\mathbf{S}^{\mathbf{4}}$. \\ Universitas Veteran Bangun Nusantara \\ Email; Natasyadianpermata18@gmail.com
}

\begin{abstract}
This study aims to determine the learning formulation that is suitable for students with mental disabilities. This type of research is qualitative research. Data analysis uses the process of data reduction, data presentation, and conclusion drawing. Planning mathematics learning for mentally disabled children at BC SLB Hamong Putro uses the 2013 curriculum implementation plan (RPP). The learning process of mathematics for mentally disabled children contains several aspects, namely the material taught is material learning that is concrete to material that is abstract, then positive giving reinforcement so that students are enthusiastic in learning, besides learning programs that are given to students individually, after that the learning evaluation process is carried out to find out the ability of students, then the material conveyed must be material that supports the achievement of set goals, and the material conveyed must be material that is useful for everyday life. The evaluation and follow-up steps that must be done are the preparation of an Individual Learning Program (PPI) and follow-up activities after conducting an evaluation in the form of special guidance carried out by teachers for mentally disabled students.
\end{abstract}

Keyword; mentally disabled students, learning formulations

\section{PENDAHULUAN}

Pendidikan itu diperuntukan manusia yang hidup tanpa membeda-bedakan status sosial, ekonomi, normal maupun yang berkebutuhan khusus. Pendidikan merupakan hak dasar (fundamental right) untuk semua anak bahkan dalam situasi apapun tanpa adanya diskriminasi. Tanpa diskriminasi inilah yang mendasari bahwa pendidikan juga merupakan hak dasar bagi anak berkebutuhan khusus. (Arifin dalam Balitbangham: 2014). Anak berkebutuhan khusus (ABK), mendapatkan hak yang sama dalam pemenuhan pendidikan. Anak berkebutuhan khusus ini juga berhak mendapatkan pendidikan seperti halnya anak normal lainnya, agar dapat hidup bermasyarakat dengan baik, dapat hidup mandiri, dan juga menjadi penerus bangsa dan negara sesuai denga yang diharapkan.

Di Indonesia hak pendidikan bagi anak berkebutuhan khusus sudah diatur dalam Undang-undang Sistem Pendidikan Nasional No. 20 Tahun 2003 pasal 32. Di dalam undangundang tersebut disebutkan bahwa pendidikan khusus merupakan pendidikan yang diperutukan bagi peserta didik yang memiliki tingkat kesulitan dalam mengikuti proses pembelajaran karena kelainan fisik, emosional, mental, dan sosial dan/atau memiliki potensi kecerdasan dan bakat istimewa. Hal tersebut semakin menegaskan bahwa anak berkebutuhan khusus memiliki hak untuk memperoleh pendidikan yang layak. Menurut Permendiknas No. 70 Tahun 2009 tentang Pendidikan Inklusif Bagi Peserta Didik yang Memiliki Kelainan dan Memiliki Potensi Kecerdasan dan/atau Bakat Istimewa. Pendidikan 
inklusif didefinisikan sebagai sistem penyelenggaraan pendidikan yang memberikan kesempatan pada semua peserta didik yang memiliki kelainan dan memiliki potensi kecerdasan dan/atau bakat istimewa untuk mengikuti pendidikan atau pembelajaran dalam lingkungan pendidikan secara bersama sama dengan peserta didik pada umumnya atau melalui sekolah khusus/sekolah luarbiasa (SLB).

Anak berkebutuhan khusus (ABK) adalah anak yang memiliki hambatan fisik, mental, emosional, sosial dan memiliki potensi kecerdasan atau bakat istimewa untuk mengikuti pendidikan atau pembelajaran dalam lingkungan pendidikan. Dalam praktik pendidikan inklusi, guru menyiapkan program pembelajaran yang disesuaikan dengan kemampuan awal dan juga kebutuhan belajar peserta didik.

Salah satu hal yang termasuk klasifikasi anak berkebutuhan khusus (ABK) adalah anak tunagrahita. Menurut Mumpuniarti $(2003,23)$ tunagrahita adalah anak yang memiliki hambatan di bidang mental. Kemampuan akademis yang dimiliki anak tunagrahita dibawah rata-rata sehingga perkembangannya terlambat dibandingkan dengan anak normal. Oleh sebab itu perlu adanya perhatian khusus terhadap anak tunagrahita dari guru atau pembimbing agar perkembangan anak tunagrahita dapat dicapai sesuai kemampuan yang dimiliki.

Anak tunagrahita tidak hanya sekedar memiliki permasalahan dalam hal akademiknya saja tetapi juga masalah pengelolaan emosi. Melihat karakteristik anak tunagrahita di atas sudah semestinya guru sebagai pendidik bidang studi matematika pandai dalam memahami karakteristik dan kompetensi yang dimiliki anak terutama tunagrahita, sehingga guru kelas bila sedang mengajar mata pelajaran matematika dapat menyiapkan formulasi pembelajaran yang baik dan mampu menentukan proses pembelajaran mana saja yang harus dilalui. Harapan lain adalah agar anak tersebut mampu mendapatkan nilai yang maksimal dan pastinya mereka dapat mengingat materi yang telah diberikan dan dapat digunakan seharihari.

Dalam menentukan strategi yang efektif, guru harus memperhatikan tujuan pelaksanaan pembelajaran, karakteristik anak tunagrahita, dan ketersediaan sarana dan prasarana. Strategi yang digunakan dalam pembelajaran pada anak tunagrahita adalah strategi yang diindividualisasikan, kooperatif dan modifikasi tingkah laku. Pendekatan pembelajaran bagi anak tunagrahita juga memerlukan berbagai pertimbangan berdasarkan karakteristik dari anak tersebut. Pendekatan yang cenderung digunakan adalah pendekatan modifikasi tingkah laku, karena perkembangan tingkah laku anak tunagrahita mengalami hambatan, sehingga tingkah laku yang dikembangkan harus bisa diamati.

Selain dalam kemampuan guru, perbedaan juga terdapat pada sarana dan prasarana. Materi yang dirancang harus lebih fleksibel agar dengan mudah tersampaikan kepada anak 
tunagrahita. Materi yang disampaiakan tidak terbatas pada bidang akademik saja, tetapi guru juga perlu memberikan pengetahuan yang fungsional dalam kehidupannya. Salah satu sekolah yang ditunjuk untuk menyelenggarakan pembelajaran anak tunagrahita adalah SLB B-C Hamong Putro Jombor. Pada penelitian kali ini peneliti fokuskan pada pembelajaran matematika. Hal ini dikarenakan mata pelajaran matematika adalah matapelajaran yang sulit untuk dipahami dan masih kurang memenuhi standar nilai atau dalam artian masih banyak yang belum tuntas

\section{METODE}

Jenis penelitian ini adalah kualitatif. Pengumpulan data dilakukan dengan teknik observasi dan mengamati keadaan dalam kelas saat proses pembelajaran berlangsung serta mendokumentasikan transkrip nilai yang diperoleh anak. Subjek penelitian ini adalah anak tunagrahita yang berjumlah tiga anak. Tahap analisis data melalui tiga jalur analisis data kualitatif, yaitu reduksi data, penyajian data, dan penarikan kesimpulan (Miles dan Huberman, 1992). Reduksi data adalah proses pemilihan, pemusatan perhatian pada penyederhanaan, pengabstrakan dan transformasi data kasar yang muncul dari catatancatatan tertulis di lapangan. Proses ini berlangsung terus menerus selama penelitian berlangsung, bahkan sebelum data benar-benar terkumpul sebagaimana terlihat dari kerangka konseptual penelitian, permasalahan studi, dan pendekatan pengumpulan data yang dipilih peneliti. Reduksi data merupakan bentuk analisis yang menajamkan, menggolongkan, mengarahkan, membuang yang tidak perlu dan mengorganisasi data dengan cara sedemikian rupa sehingga kesimpulan akhir dapat diambil. Reduksi tidak perlu diartikan sebagai kuantifikasi data. Sementara itu penyajian data adalah kegiatan ketika sekumpulan informasi disusun sehingga memberi kemungkinan akan adanya penarikan kesimpulan serta pengambilan tindakan.

\section{HASIL DAN PEMBAHASAN}

Hasil penelitian menunjukkan bahwa kepala sekolah SLB B-C Hamong Putro, guru kelas, serta wali murid mempunyai pemahaman tersendiri terkait formulasi dan proses pembelajaran matematika yang tepat bagi anak tunagrahita. Kepala sekolah SLB B-C Hamong Putro beserta guru kelas dapat mengetahui formulasi pembelajaran matematika yang cocok bagi anak tunagrahita dan proses pembelajaran matematika secara spesifik. Sementara itu wali murid masih belum dapat memahami formulasi dan proses pembelajaran matematika secara spesifik dan cocok bagi anak tunagrahita.

Formulasi pembelajaran matematika bagi anak tunagrahita terdiri dari beberapa bagian yaitu:1) Kesiapan guru dalam mengajar mata pelajaran matematika serta 
perencanaan pembelajaran matematika, (2) Pelaksanaan proses pembelajaran matematika yang dilakukan, (3) Evaluasi dan tindak lanjut dari proses pembelajaran yang telah berlangsung. Adapun deskripsi dari masing-masing bagian adalah sebagai berikut;

\section{Perencanaan pembelajaran matematika yang cocok bagi anak tunagrahita}

Perencanaan pembelajaran matematika bagi anak tunagrahita di SLB B-C Hamong Putro tertuang dalam Rencana Pelaksanaan Pembelajaran (RPP) standar kurikulum 2013. Anak berkebutuhan khusus memiliki kurikulum dan buku pembelajaran matematika secara khusus. Standar capaian yang mereka dapatkan juga berbeda dengan standar pencapaian kurikulum anak normal.

\section{Pelaksanaan proses pembelajaran}

Tahapan proses pembelajaran matematika pada anak tunagrahita terdiri dari enam bagian yang harus dilakukan yakni;

a. Pemberian materi matematika dari yang mudah ke materi yang sulit. Langkah awal pembelajaran matematika diberikan secara klasikal, hal ini dilakukan untuk mengetahui seberapa besar kemampuan anak dalam proses berpikir dan menalar. Menurut Abdurrachman (Maria J Wantah, 2007: 1) Ciri utama anak tunagrahita adalah lemah dalam berpikir dan menalar. Kurangnya kemampuan anak untuk berpikir dan menalar mengakibatkan sulitnya anak menangkap materi yang diberikan guru. Guru harus mengetahui kemampuan anak di awal pembelajaran. Dengan melihat karakteristik pembelajaran matematika pada anak tunagrahita sebaiknya materi yang diberikan bersifat individual dan berdasarkan kemampua awal anak, karena anak akan lebih lambat menerima informasi dibandingkan dengan anak normal. Materi yang diberikan harus diulang-ulang agar anak tidak mudah lupa. Selain itu, anak juga memerlukan pendampingan intensif. Pemberian materi pembelajaran yang diberikan harus dari yang mudah ke yang sulit, dari yangt konkrit ke abstrak. Hal ini dilakukan agar cara berpikir anak tunagrahita dapat berkembang.

b. Pemberian positive reinforcement. Menurut Mumpuniarti (2007, 140) positif reinforcement diberikan kepada anak tunagrahita untuk mengikuti tanggapan yang tepat dalam pembelajaran matematika. Hal ini berlaku sebagai penguat ekstrinsik, misalnya; hadiah, pujian, dan ganjaran. Tetapi selama kegiatan penelitian dilakukan, hampir tidak tampak pemberian positif reinforcement oleh guru mata pelajaran terhadap ketiga subjek. Hal yang banyak ditemukan adalah pemberian teguran terhadap anak yang mengganggu kegiatan pembelajaran seperti berteriak-teriak. Guru hanya menegur dengan ucapan "ssst, diam jangan ganggu temannya!". Ketika ada anak yang bisa mengerjakan dengan baik, guru memberikan pujian seperti "bagus, pintar". Ketiga subjek tidak pernah membuat gaduh dan mengganggu pembelajaran selama 
kegiatan pembelajaran berlangsung, Ketiga subjek selalu terlihat semangat selama mengikuti proses pembelajaran.

c. Program yang bersifat individual. Anak tunagrahita akan mengalami kesulitan pembelajaran akademik maupun non akademik. Mereka akan kesulitan menangkap materi pelajaran. Mereka memiliki daya berpikir yang terbatas dan daya ingat yang lemah Astati dkk, (2003: 8). Dengan melihat karakteristik pembelajaran pada anak tunagrahita, sebaiknya materi yang diberikan bersifat individual dan berdasarkan kemampua awal anak, karena anak akan lebih lambat dalam menerima informasi. Materi yang diberikan harus diulang-ulang agar anak tidak mudah lupa. Pendapat lain juga dikemukakan oleh Lay Kekeh (2007: 176) yang mengemukkan prinsip umum dalam pendidikan inklusif yang salah satunya adalah prinsip individualisasi. Dimana guru perlu mengenal kemampuan awal dan karakteristik anak secara mendalam baik dari segi kemampuan maupun kekurangan. Selama kegiatan pembelajaran matematika berlangsung pada anak tunagrahita di SLB B-C Hamong Putro, materi yang diberikan guru bersifat khusus, diberikan secara klasikal dan juga tersusun secara individual. Hal ini sesuai dengan pernyataan Mumpuniarti (2007, 140) bahwa pendekatan pembelajaran matematika untuk anak tunagrahita harus terprogram untuk ketersediaan pembelajaran yang bersifat individual sehingga anak dapat mengikuti sesuai dengan kemampuannya.

d. Pelaksanaan evaluasi. Mumpuniarti (2007: 140), menyatakan perlunya evaluasi dalam pembelajaran matematika untuk anak tunagrahita. Evaluasi dilakukan guna menentukan cara belajar anak di setiap materi pengajaran agar menjadi lebih efektif. Pembelajaran akan lebih efektif apabila materi matematika yang disampaikan disusun berdasarkan hasil assesmen dan mengacu pada kemampuan awal anak. Setelah pembelajaran berlangsung guru untuk melakukan evaluasi guna menentukan apakah program yang diberikan sudah sesuai, menunjukkan peningkatan atau malah sebaliknya. Selama pelaksanaan pembelajaran matematika pada anak tunagrahita di SLB B-C Hamong Putro berlangsung, terlihat pelaksanaan evaluasi dikarenakan ada program khusus yang bersifat individual yang disusun sebelumnya. Evaluasi yang dilakukan sama dengan anak normal yang lain, yaitu pelaksanaan ujian tengan semester dan ujian akhir semester.

e. Materi yang disampaikan mendukung tercapainya tujuan yang telah ditetapkan sebelumnya. Selama pelaksanaan pembelajaran matematika pada anak tunagrahita di SLB B-C Hamong Putro berlangsung, materi yang diberikan adalah bersifat khusus, diberikan secara klasikal, dan ada program yang tersusun secara individual sehingga ada tujuan khusus yang ditetapkan untuk setiap subjek. Hal ini sejalan dengan 
pendapat Mumpuniarti $(2007,140)$ bahwa dalam pendekatan pembelajaran matematika anak tunagrahita, materi yang diberikan kepada anak harus mendukung tercapainya tujuan khusus yang telah ditentukan sebelumnya. Materi yang diberikan harus sesuai dengan batas kemampuan anak. Guru dengan sabar mengajari masingmasing anak agar mampu mencapai ketuntasan nilai.

f. Materi yang disampaikan bermanfaat bagi kehidupan sehari-hari. Menurut Mohammad Efendi, (2006: 90). Anak tunagrahita tidak mampu mengikuti program di sekolah biasa tetapi masih memiliki kemampuan yang dapat dikembangkan, diantaranya adalah membaca, menulis, mengeja, menghitung, menyesuaikan diri dan tidak menggantungkan diri kepada orang lain, serta keterampilan sederhana untuk kepentingan kerja dikemudian hari. Selama kegiatan pembelajaran matematika pada anak tunagrahita di SLB B-C Hamong Putro berlangsung, materi yang disampaikan bersangkutan dengan bangun datar dan bangun ruang seperti bentuk dan sifatnya. Dengan mengetahui aspek-aspek dasar dalam bangun itu, anak dapat mengimplementasikan dalam kehidupan sehari-hari seperti dapat mengetahui bentuk dari bangun itu dan membuat benda kerajinan.

\section{Evaluasi dan Tindak Lanjut}

Evaluasi dan tindak lanjut harian merupakan serangkaian dari proses pembelajaran pada satu pertemuan pelajaran matematika di kelas inklusif. Di dalam proses ini, guru sudah mengantongi informasi mengenai perkembangan anak terkait tingkat pemahaman konsep anak. Informasi yang sudah diperoleh oleh guru matematika mengenai perkembangan anak dan kesulitan belajar anak didiskusikan bersama wali murid guna memperoleh solusi yang tepat dan akan di tuangakan ke dalam kegiatan tindak lanjut yang tersusun dalam Program Pembelajaran Individu (PPI). Kegiatan tindak lanjut dilakukan setelah melakukan evaluasi, yakni berupa bimbingan khusus terhadap anak. Kegiatan bimbingan khusus dilakukan tergantung hasil evaluasi harian yang sudah didapat oleh guru selama proses pembelajaran matematika. Sebagai contoh ketika anak tunagrahita masih belum memahami konsep bangun datar dan bangun ruang, maka treatment yang dilakukan guru adalah menggunakan media kongkrit berupa alat peraga bangun ruang seperti balok, kotak kerdus, yang tujuannya adalah agar anak dapat terbiasa dengan materi yang diterima sehingga konsep dapat dipahami dengan baik. Namun, apabila di dalam pembelajaran anak sudah dapat memahami konsep, maka treatment yang dilakukan guru hanya melakukan penguatan konsep materi dengan menggunakan latihan soal-soal.

Kompleksitas pelaksanaan pembelajaran matematika yang sudah dilaksanakan di SLB B-C Hamong Putro sudah sesuai dengan apa yang tertuang di dalam 
Permendiknas Nomor 70 tahun 2009 tentang Pendidikan Inklusif Bagi Peserta Didik yang Memiliki Kelainan dan Memiliki Potensi Kecerdasan dan/atau Bakat Istimewa mengenai pelaksanaan pembelajaran di kelas inklusi. Guru pelajaran matematika selalu mengkondisikan anak baik secara psikis dan fisik. Hal tersebut sangat baik karena anak dapat siap menerima pelajaran dengan tenang tanpa adanya suatu tekanan dan termotivasi.

Proses pembelajaran matematika anak tunagrahita terdiri dari tahapan penanaman konsep, tahap pemahaman, dan tahap keterampilan. Adapun deskripsi dari masing-masing bagian adalah sebagai berikut;

a. Tahap penanaman konsep

Tahap penanaman konsep yang dilakukan untuk anak tunagrahita di SLB B-C Hamong Putro adalah dengan mengaitkan materi yang hendak diajarkan saat ini dengan materi yang telah diajarkan. Kegiatan pembelajaran memberikan fungsi panca indra seperti melihat, mendengar, meraba, memindahkan objek-objek, dan berkomunikasi.

b. Tahap pemahaman

Tahap pemahaman yang dilakukan di SLB B-C Hamong Putro adalah dengan cara memperluas konsep matematika yang telah dipelajari. Penanaman konsep dilakukan dan diterapkan untuk memecahkan permasalahan yang dialami anak tersebut. Guru harus menggunakan alat bantu untuk membentuk pemahaman anak. Hal ini dilakukan karena pada umumnya anak tunagrahita sangat sulit memahami materi apabila hanya dijelaskan tanpa memberikan contoh konkrit.

c. Tahap keterampilan

Tahap terakhir yang harus dilalui selama proses pembelajaran anak tunagrahita adalah keterampilan. Keterampilan yang dilakukan anak tunagrahita di SLB B-C Hamong Putro adalah melatih anak untuk menggunakan konsep-konsep matematika yang telah dipelajari sebelumnya.

Dari uraian di atas dapat dimaknai bahwa pembelajaran matematika bagi anak tunagrahita di SLB B-C Hamong Putro didasarkan pada materi matematika yang dapat diaplikasikan untuk kehidupan sehari-hari. Anak tunagrahita diharapkan mampu menguasai keterampilan-keterampilan menghitung bilangan, pengangkaan, hubungan, pengukuran, pengoperasian angka, pengoperasian angka rasional dan pemecahan masalah. Namun, anak tunagrahita di SLB B-C Hamong Putro perlu memahami konsep yang diberikan. Materi harus bersifat mendalam agar anak dapat terampil menggunakan konsep-konsep matematika yang diajarkan sebelumnya. Materi dipelajari untuk memecahkan permasalahan di lingkungan 
mereka. Dalam hal ini, guru kelas tunagrahita harus menggunakan alat bantu media pembelajaran guna membentuk pemahaman yakni dengan benda konkrit di sekitar anak.

\section{KESIMPULAN}

Berdasarkan hasil penelitian dan pembahasan yang telah dideskripsikan di atas, dapat disimpulkan bahwa pelaksanaan dan proses pembelajaran matematika untuk anak tunagrahita di SLB B-C Hamong Putro terdiri dari berbagai tahapan, yang pertama adalah proses pembelajaran yang didasarkan pada materi matematika dapat diaplikasikan dalam kehidupan sehari-hari. Anak tunagrahita diharapkan mampu menguasai keterampilanketerampilan menghitung bilangan, pengangkaan, hubungan, pengukuran, pengoperasian angka, pengoperasian angka rasional dan pemecahan masalah. Namun, pada anak tunagrahita di SLB B-C Hamong Putro perlu memahami konsep yang diberikan. Materi harus bersifat mendalam agar anak terampil menggunakan konsep-konsep matematika yang diajarkan sebelumnya. Dalam hal ini, guru kelas tunagrahita harus menggunakan alat bantu media pembelajaran guna membentuk pemahaman yakni dengan benda konkrit di sekitar anak. Sedangkan pelaksanaan pembelajaran matematika terdiri dari; (1) Perencanaan pembelajaran matematika dengan menggunakan Rencana Pelaksanaan Pembelajaran (RPP) standar kurikulum 2013; (2) Proses pembelajaran matematika anak tunagrahita mengandung beberapa aspek yaitu materi yang diajarkan adalah materi pembelajaran mulai dari yang bersifat konkrit ke materi yang berifat abstrak. Pemberian positive reinforcement agar anak semangat dalam belajar. Selain itu program pembelajaran yang diberikan adalah secara individual, baru setelah itu untuk dilakukan proses evaluasi pembelajaran guna mengetahui kemampuan anak. Materi yang disampaikan haruslah materi yang mendukung tercapainya tujuan yang telah ditetapkan. Materi yang disampaikan haruslah materi yang bermanfaat bagi kehidupan sehari-hari; (3) Tahap evaluasi dan tindak lanjut yang harus dilakukan adalah penyusunan Program Pembelajaran Individu (PPI). Kegiatan tindak lanjut dilakukan setelah adanya evaluasi yaitu berupa bimbingan khusus.

\section{ACKNOWLEDGEMENT}

Terimakasih peneliti ucapkan kepada Ristek Dikti yang telah mendanai penelitian ini sehingga berjalan dengan lancar. Tidak lupa peneliti ucapkan terimakasih kepada pembimbing Meidawati Suswandari S.Pd, M.Pd yang telah bersedia membantu proses penyusunan hasil penelitian. Ucapan terimakasih tidak lupa peneliti ucapkan kepada pihak sekolah SLB B-C Hamong Putro yang telah mengizinkan peneliti untuk melakukan penelitian di lembaga tersebut. 


\section{BIBLIOGRAFI}

Ana Lisdiana. (2012). Prinsip Pengembangan Atensi pada Anak lamban Belajar: Modul Materi Pokok Program Diklat Kompetensi Pengembangan Fungsi Kognisi pada Anak Lamban Belajar bagi Guru di Sekolah Inklusi Jenjang Lanjut. Kemendikbud Press.

ASB. (2011). Panduan 3: Pengelolaan Sekolah Inklusi. Disdikpora Press.

Astati, Teguh Santosa, \& Soedarini. (2003). Program Khusus Bina Diri Bisakah Aku Mandiri. Depdiknas Press.

Efendi, Mohammad. (2006). Pengantar Psikopedagogik Anak Berkelainan. Bumi Aksara Press.

Kekeh, Lay. (2007). Manajemen Pendidikan Inklusif. Depdiknas Press.

Kemis, Ati. (2013). Pendidikan Anak Berkebutuhan Khusus Tunagrahita. Luxima Press.

Mudjito. (2014). Memahami Pendidikan Inklusi dan Pendidikan Layanan Khusus. Pustaka Pelajar Press.

Mumpuniarti. (2003). Ortodidaktik Tunagrahita. FKIP UNY Press. 